\title{
Dysaesthesias and dysautonomia: a self-limited syndrome of painful dysaesthesias and autonomic dysfunction in childhood
}

\author{
RUTH NASS, ABE CHUTORIAN \\ From the Columbia Presbyterian Medical Center, Department of Neurology, New York, USA
}

SUMMARY Three children with an acute self-limited syndrome characterised by painful dysaethesias, hypertension, and autonomic dysfunction, in the absence of motor and reflex abnormalities, are presented. They appear to have had a variant of acute polyneuritis involving sensory and autonomic systems. The pathophysiology of hypertension in the Guillain-Barré syndrome and of acute pandysautonomia is discussed. Excessive adrenergic function is considered as a cause of the pain component of the syndrome.

Three children were seen within 1 year with an acute self-limited syndrome consisting of (1) painful symmetrical dysaesthesias of the distal more than proximal extremities, severe enough to result in selfimposed immobilisation, (2) sustained hypertension, (3) variable signs, symptoms, and laboratory findings of autonomic dysfunction, (4) normal motor function and deep tendon reflexes. Although this pattern of sensory and autonomic dysfunction has been seen in the Guillain-Barré syndrome, the complete absence of motor system involvement precludes this diagnosis. ${ }^{1}$ These cases cannot be considered examples of acute pan-dysautonomia, first described by Young ${ }^{2}$ in 1969 and since reported in five children $^{3-7}$ because of the prominent sensory symptoms and presence of sustained hypertension, rather than postural hypotension.

\section{Case reports}

Case 1 A healthy eleven-year-old boy developed an upper respiratory infection and fever in February, 1979. During the following days he developed first, generalised pruritis, and then painful, burning dysaesthesias beginning in the feet and ascending to involve the arms. One

Address for reprint requests: Ruth Nass MD, New York Hospital, Department of Neurology, 525 E 68 St, New York, New York 10021, USA.

Received 12 May 1981 and in revised form 17 September 1981 Accepted 1 November 1981 week later he was found to be hypertensive. Prednisone was given for five days, without benefit. At that time, and throughout his illness, he denied any change in bladder or $\mathbb{D}$

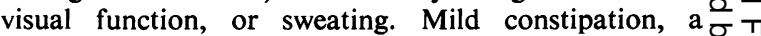
thickening of saliva, and an evanescent erythematous $\mathbb{D}$ blotchy skin rash were noted. He was more irritable than usual, sometimes irrational, but always alert. Three weeks later he was admitted to Babies Hospital. He was afebrile, blood pressure was $155 / 125 \mathrm{~mm} \mathrm{Hg}$ with no orthostatic change or response to Valsalva manoeuvre, and heart rate was 120 beats per minute. He kept himself immobile and maintained all extremities in flexed postures. On general physical examinations there was dermatographia, evanescent blotching of the skin, and piloerection. Mild non-pitting oedema was present in both hands and feet. He was irritable, but cognitive function was normal. The cranial nerves including pupillary response were normal, as were the motor and sensory systems. Deep tendon reflexes were brisk with no clonus. He strenously resisted attempts to stretch the heel cords and hamstrings, and complained of hyperaesthesia when the distal portions of the legs were touched. The hypertension responded to propanolol $30 \mathrm{mg}$ three times a day. By April he was normotensive and not receiving medication. After one month of illness the dysaesthesia's began to descend, involving only the ankles by April, and finally disappearing in June. Skin changes and postural guarding disappeared at the same time.

Blood count, ESR, biochemical profile, ANA, LE preparation were normal. An excretion pyelogram was normal. CSF after three weeks of illness revealed five mononuclear cells and a protein of $0.6 \times 8 \mathrm{~g} / \mathrm{l}$, but was normal in the fourth week of illness. EMG and nerve conduction studies revealed a mild sensory neuropathy 
with prolonged median $(3.2 \mathrm{~ms})$ and ulnar $(3.2 \mathrm{~ms})$ sensory latencies, slowing of sensory velocities as compared to motor in these same nerves (median 46 and 57 $\mathrm{m} / \mathrm{s}$, ulnar 44 and $49 \mathrm{~m} / \mathrm{s}$ ), and absent sural responses. Testing of autonomic function was limited to noninvasive procedures. The pupils showed a normal response to mecholyl, no response to cocaine, though pupils dilated with excitement, and decreased lachrymation on the Schirmer test. An intradermal histamine test was normal. Urinary VMA was $6.5 \mathrm{mg}$ (normal 1-5) per $24 \mathrm{~h}$. Urinary porphyrins were normal. Plasma renin was normal, plasma catecholamines were elevated: epinephrine $83 \mathrm{pg} / \mathrm{ml}$ (normal $20 \pm 7 \cdot 2 \mathrm{pg} / \mathrm{ml}$ ), norepinephrine $402 \mathrm{pg} / \mathrm{ml}$ (normal $195 \pm 86 \mathrm{pg} / \mathrm{ml}$ ), dopamine 32 $\mathrm{pg} / \mathrm{ml}$ (normal $3 \cdot 4 \pm 6 \mathrm{pg} / \mathrm{ml}$ ).

Case 2 A healthy ten-year-old boy began complaining of burning hands and feet in August of 1979. By September the dysaesthesias involved the proximal limbs as well and were relieved only by warm baths. Phenytoin offered no relief. On admission in October he denied prodromal illness, or changes in bowel or bladder function, visual blurring, abnormal sweating, or blotching of the skin. Examination revealed an irritable child, who kept his legs flexed. Blood pressure was $130 / 98 \mathrm{~mm} \mathrm{Hg}$ sitting, 130/90 $\mathrm{mm} \mathrm{Hg}$ lying, heart rate was 100 beats per minute and Valsalva response was absent. His temperature was $99 \cdot 5^{\circ} \mathrm{C}$. Neurological examination was normal, except for brisk reflexes. Carbamazepine offered some relief of pain as gauged by the number of baths he took per day. Two weeks later his blood pressure was normal without treatment. He returned to hospital in late November complaining of poor appetite, frequent abdominal cramps and a marked weight loss. Over the weeks his dysaesthesias had receded and now involved only the feet. Neurological examination was unchanged. Barium meal with fluoroscopic assessment of motility and a barium enema were normal. He was encouraged to eat and discharged when he began gaining weight. Blood count, ESR, heterophile, cryoglobulins, ANA, lead level, urinary prophyrins, and urinary VMA were normal. Biochemical profile was normal except for a mild elevation of liver enzymes, (normal one month later). Radiographs showed osteoporosis of the feet. CSF, EMG and nerve conduction studies, and CT scan were normal. Plasma $a$-galactosidase A was normal. EEG showed background slowing and disorganisation consistent with an encephalopathy. Sleep pattern was abnormal with periodicity of $K$ complexes and persistence in deep sleep. Brain stem auditory evoked responses were normal. Mecholyl produced brisk miosis bilaterally; lachymation was decreased by the Schirmer test; intradermal histamine test was normal. Peripheral renin activity was in the normal range, but the response to postural change was muted (supine $1.44 \mathrm{ng} / \mathrm{ml} / \mathrm{h}$, standing 2.07).

Case 3 A previously well eight-year-old girl had an upper respiratory infection in September 1979. Two weeks later she began to complain of painful burning feet. Within a few days the dysaesthesias ascended to involve her entire lower extremities bilaterally, rendering her immobile by mid-October. Only cold compresses relieved the discomfort. When admitted in November she denied any change in lachymation or sweating, bladder dysfunction, blurred vision, or rash. She had been somewhat constipated and elevated blood pressures had been recorded during the previous two months. On examination she was an irritable child with normal vital signs. Neurological examination was entirely normal. Carbamazepine offered some relief. Over the following weeks her dysaesthesias descended and disappeared.

Blood count, ESR, ANA, heterophile, lead level, and urine for heavy metals were normal. Biochemical profile except for mild elevation of liver enzymes was normal. CSF contained no cells with a protein of $0.29 \mathrm{~g} / \mathrm{l}$. An EEG showed intermittent rhythmic slowing. EMG was normal, but peroneal nerve sensory conduction was mildly slowed at $37.9 \mathrm{~m} / \mathrm{s}$. Mecholyl produced brisk miosis; lachymation was decreased on Schirmer testing, and intradermal histamine produced a normal wheal and normal flare which however was delayed (appearing at 18 minutes). Urinary HVA $(4.2 \mathrm{mg})$ and VMA $(0.8 \mathrm{mg} /$ $24 \mathrm{~h}$ ) were normal. Plasma renin activity was depressed and postural fluctuation was absent (supine $0.54 \mathrm{ng} / \mathrm{ml} / \mathrm{h}$, standing 0.57).

\section{Discussion}

These three children presented with spontaneous burning pain and symmetrical hyperpathia in the limbs. Hypertension was present. Other than a remarkably similar irritability and strenuous guarding of the immobilised limb joints, they had a normal general neurological examination, but various signs, symptoms and laboratory findings of autonomic dysfunction were found.

Autonomic dysfunction in association with the Guillain-Barré syndrome has received increasing attention in recent years as a major cause of unexpected mortality in an era of excellent ventilatory support. Hypertension has been found in from $12 \%$ (children) to $22 \%^{9}$ to $61 \%$ of patients. Lesions within the autonomic nervous system (in intermediolateral columns of the spinal cord, sympathetic trunk and ganglia and cranial nerves IX and X) have been documented in patients with and without reported autonomic symptoms. ${ }^{11}$ Lichtenfeld $^{10}$ proposed that sympathetic hyperfunction may be responsible for hypertension in some cases, suggesting that "a damaged sympathetic nervous system might overact or act spontaneously overriding central control mechanisms in a fashion analogous to the dysesthesias that occur when a sensory nerve is damaged." Although he was unable to document adrenergic hyperfunction as reflected in urinary catechols, this has been documented by Mitchell,12 Davies, ${ }^{13}$ and Davidson. ${ }^{14}$ Plasma norephinephrine has been found to be elevated in essential hypertension by most investigators, ${ }^{15} 16$ but the finding of excess catecholamines does not indicate the source 
of the problem. Isometric muscle contraction may cause hypertension, ${ }^{17}$ so a possible interpretation is that the hypertension resulted from the postures adopted by these children to minimise their pain.

Catecholamines may not be the only humoral factor implicated. Stapleton's group ${ }^{18}$ reported an infant with classic Guillain-Barré syndrome and hypertension, who had normal urinary catechols but elevated plasma renin.

The autonomic dysfunction in the Guillain-Barré syndrome involves a mixture of sympathetic and parasympathetic hypofunction and hyperfunction. Young ${ }^{2}$ reported a forty-seven-year-old man with pure panautonomic (postganglionic) hypofunction of acute onset and with recovery over eighteen months. CSF protein was elevated. Sural nerve biopsy showed an increase in the unmyelinated small fibres thought to reflect sprouting and regeneration after axonal damage. In light of Appenzeller's demonstration ${ }^{19}$ of an immune mediated animal model for autonomic neuropathy, Young suggested that this disease was the autonomic equivalent of Guillain-Barré syndrome. Since then, at least fifteen cases have been reported-five in children, and all but three 620 have shown postural hypotension. Four of the reported cases $^{3-520}$ (all aged under twenty years) had abnormal EEGs or seizures associated with their illness, or both. These cases, as well as our patients, may be examples of the encephalopathic component often seen in children, but not adults, with acute peripheral neuropathies. ${ }^{21}$ Colon et $a^{22}$ also have described a nine-year-old child with an acute onset of sensory and autonomic neuropathy, including postural hypotension, and an elevated CSF protein. Although there was EMG and nerve conduction evidence of a sensory neuropathy, and examination of the sural nerve showed loss of unmyelinated fibres and axonal degeneration, this child had no pain.

Observations from electrical stimulation of exposed sural nerves show that pain is felt when small myelinated and unmyelinated fibres are stimulated; burning pain in particular is associated with stimulation of the gamma component of the $\mathrm{A}$ fibre group. ${ }^{23}$ Nonetheless, investigators ${ }^{24-26}$ have been unable to demonstrate by morphologic analysis a distinctive pattern of fibre loss associated with the occurrence of pain. Wall suggests that damage to a peripheral sensory axon produces a multilevel reaction in other central and peripheral cells with which it is in communication; and regenerating nerve sprouts and the membrane of the axon beyond the damage become abnormally sensitive to norepinephrine. ${ }^{27}$ Torebjork and Hallin ${ }^{28}$ documented in a patient with causalgia lowering of the temperature pain threshold by norepinephrine; and conversely documented an association between lessening of pain and inhibition of sympathetic activity. Improvement in the dyaesthesias in case 1 coincided with the institution of propanolol.

Reflex sympathetic dystrophy clinically involves only an extremity or appendage and occurs most commonly after traumatic injury. The pain in this syndrome, the vasomotor and sudanomotor disturbances, trophic skin and bone changes ${ }^{29}$ resemble those that were seen in our patients. Physiological studies in reflex sympathetic dystrophy suggest sympathetic nervous system overactivity. ${ }^{30}$

We thank Dr Alex Stalcup of the Pediatric Pulmonary division of Babies Hospital for his help in performing and interpreting the plasma catecholamine and renin studies.

\section{References}

1 NINCDS committee. Criteria for the diagnosis of Guillain-Barré. Ann Neurol 1978;3:565.

2 Young R, Asbury A, Corbett J, Adams R. Pure pandysautonomia with recovery: Description and discussion of diagnostic criteria. Brain 1975;98: 613-36.

${ }^{3}$ Christie D. GI manifestations of "acquired dysautonomic" syndrome. J Pediatr 1979;90:625-32.

"Harik SI, Ghandour MH, Farak FS, Afifi AK. Post ganglionic cholinergic dysautonomia. Ann Neurol 1977;1:393-6.

${ }^{5}$ Hopkins A, Neville B, Bannister R. Autonomic neuropathy of acute onset. Lancet 1974;1:769-71.

${ }^{6}$ Thomashefsky A, Horwitz S, Feingold M. Acute autonomic neuropathy. Neurology $(N y)$ 1972;22: 251-5.

' Yahr MD, Frontera A. Acute autonomic neuropathy: its occurrence in infectious mononucleosis. Arch Neurol 1975;32:132-3.

${ }^{8}$ Gecow A, Pamela I. Autonomic disturbances in Guillain-Barré in children. Polish Med J 1971;10: 1230-5.

${ }^{9}$ Matsuyama H, Haymaker W. Distribution of lesions in Guillain-Barré, with emphasis on involvement of sympathetic system. Acta Neuropathol 1966;8:37-42.

${ }^{10}$ Lichtenfeld P. Autonomic dysfunction in GuillainBarré. Am J Med 1971;50:772-80.

${ }^{11}$ Asbury A. The inflammatory lesions of idiopathic polyneuritis. Medicine 1969;48:173-80.

${ }^{12}$ Mitchell P, Meilman E. Mechanism of hypertension in Guillain-Barré. Am J Med 1967;42:986-94.

${ }^{13}$ Davies A, Dingle H. Observations on cardiovascular and neuroendocrine disturbances in Guillain-Barré. J Neurol Neurosurg Psychiatry 1972;35:176-9.

14 Davidson D, Jellinek E. Hypertension and papilledema in Guillain-Barré. J Neurol Neurosurg Psychiatry $1977 ; 40: 144-8$

${ }^{15}$ Esler M. Agreement among three different indices of sympathetic nervous system activity in essential hypertension. Mayo Clin Proc 1977;52:379-90. 
${ }^{16}$ Kopin I, Lake R, Zeigler M. Plasma levels of norepinephrine. Ann Int Med 1978;88:671-80.

${ }^{17}$ Frohlich E. The adrenergic nervous system and hypertension. Mayo Clin Proc 1977;52:379-90.

${ }^{18}$ Stapleton F, Skoglund R, Daggett R. Hypertension associated with Guillain-Barré Syndrome. Pediatrics 1978;62:588-9.

19 Appenzeller O. Experimental autonomic neuropathy. J Neurol Neurosurg Psychiatry $1965 ; 28: 510-5$.

2" Anderson O, Lindberg J, Modigh K, Reske-Nielsen E. Subacute dysautonomia with incomplete recovery. Acta Neurol Scand 1972;48:510-9.

${ }^{21}$ Chatta AS, Lombroso CT. Electroencephalographic changes in childhood optic neuritis. Electroencephalogry Clin Neurophysiol 1972;33:81-8.

${ }^{22}$ Colon RV, Snead OC, Oh S, Kashlan B. Acute autonomic and sensory neuropathy. Ann Neurol $1980 ; 8: 441-4$.

${ }^{23}$ Sunderland S. The painful nerve lesion: A prologue. In: Bonica J, Liebeskind $\mathbf{J}$, Albe-Fessard D, eds. Advances in Pain Research and Therapy. vol 3. New York: Raven Press, 1979.

${ }^{24}$ Dyke $P$, Lambert E, O'Brien P. Pain in peripheral neuropathy related to rate and kind of fiber degen- eration. Neurology $(N y)$ 1976;28:466-71.

${ }^{25}$ Collins WF, Nulsen FE, Randt CT. Relation of peripheral nerve fiber size and sensation in man. Arch Neurol 1960;3:381-97.

26 Thomas PK. Painful neuropathies. In: Bonica J, Liebeskind J, Albe-Fessard D, eds. Advances in Pain Research and Therapy. vol 3. New York: Raven Press, 1979.

27 Wall PD. Changes in damaged nerves and their sensory consequences. In: Bonica $\mathbf{J}$, Liebeskind $\mathbf{J}$, Albe-Fressard D, eds. Advances in Pain Research and Therapy. vol 3. New York: Raven Press, 1979.

28 Torebjork HE, Hallin RG. Microneurographic studies of peripheral pain mechanisms in man. In: Bonica $\mathbf{J}$, Liebeskind J, Albe-Fressard D, eds. Advances in Pain Research and Therapy. vol 3. New York: Raven Press, 1979.

${ }^{29}$ Bonica J. Causalgia and other reflex sympathetic dystrophies. In: Bonica J, Liebeskind J, AlbeFessard D, eds. Advances in Pain Research and Therapy. vol 3. New York: Raven Press, 1979.

${ }^{30}$ Kozin F, McCarty D, Sims J, Gerant M. The reflex sympathetic dystrophy syndrome. Am J Med 1976; 60:321-31. 